Iberian Journal of the History of Economic Thought

ISSN-e 2386-5768

\title{
La larga divergencia
}

Begoña Pérez Calle ${ }^{1}$

KURAN, TIMUR, La larga divergencia, Editorial Universidad de Granada, 2017, 441 pp., ISBN. 9788433860194

Casi cinco años han discurrido desde la edición original de esta obra del profesor Timur Kuran, The long divergence (Oxford University Press, 2011), y hay que comenzar por agradecer el esfuerzo de la editorial Universidad de Granada por poner a disposición de los lectores la versión en español de un trabajo fascinante y cuya trascendencia - pluridisciplinar- para el desarrollo de las competencias críticas de sociólogos, economistas, periodistas, historiadores, politólogos... actuales sobre la realidad del mundo islámico y sobre los orígenes, divergencias con Occidente y causas institucionales determinantes de su subdesarrollo económico lo convierten casi en un manual de uso para investigaciones presentes y futuras. Lectura necesaria.

La publicación inglesa de la obra en 2011 llenó un vacío existente en el debate sobre la divergencia, el cual apenas se había ocupado de Oriente Medio a pesar de haber tratado en varias ocasiones el declive económico de la región y su relación con diversos factores. En ella, Kuran transmite su visión sobre la divergencia Oriente-Occidente, partiendo de una base de análisis en la que sitúa a Oriente Medio islámico (Turquía incluida) como protagonista, y señalando un objetivo fundamental: resolver el enigma histórico de por qué esta zona presentó, finalizada la Edad Media, un retraso económico evidente con respecto a Europa occidental. El mecanismo de su análisis se centra en las causas del estancamiento institucional y el subdesarrollo, señalando la tardía adopción de herramientas clave como la legislación o las formas organizativas que permiten la movilización de los recursos productivos a gran escala, proponiendo una teoría del cambio institucional asociado a la inexistencia de la demanda de innovación organizativa a resultas de las transformaciones institucionales que sí se produjeron en los territorios europeos.

El prólogo del profesor Fernando López Castellano ofrece gran interés como lectura previa a la obra, al situar al lector en el punto de análisis en el cual la temática se encontraba, detallando cómo la literatura y las diversas críticas se habían ocupado de ello, hasta la publicación de The long divergence. A lo largo de la obra, Kuran recorre un sendero investigador y divulgador, de una significativa multidisciplinariedad, que parte de una base: el progreso de la ciencia social depende del estudio comparado de la historia. De esta forma desarrolla un argumentario cuya metodología consiste en contraponer, desde el surgimiento del Islam hasta la actualidad, qué trayectoria siguieron tanto las instituciones como las prácticas económicas en Oriente Medio, con sus equivalentes en algunos lugares de Europa Occidental, cuyas transformaciones institucionales conllevarían una innovación organizativa que Kuran asocia con el crecimiento económico moderno. Y es ahí donde surge la hipótesis del rezagamiento con respecto a Occidente: el sistema islámico clásico provocaba la aparición de impedimentos de origen puramente institucional, los cuales llevarían al estancamiento y a los obstáculos a las reformas institucionales en Oriente Medio.

Timur Kuran apunta que las principales causas de tal estancamiento económico no fueron ni el conservadurismo ni las actitudes anticientíficas — que también se dieron en Europa-, ni tampoco la colonización - no negando a ésta un papel importante-. Fue, para Kuran, la ley islámica o Sharia, la verdadera causa de la espiral descendente de subdesarrollo en la que se sumió esta

Universidad de Zaragoza.

bperez@unizar.es 
parte del mundo, pues si bien en sus primeros tiempos había desarrollado instituciones avanzadas como el derecho contractual, sin embargo no se produjo una evolución de la propia ley paralela a la evolución del mundo financiero y económico, no hubo cambios en su contenido, y ello a pesar de los numerosos intentos de reinterpretación e innovación. La cuestión es el porqué de la motivación para mantener la simplicidad de los modelos organizativos en Oriente Medio, reflexiones que Kuran une al estudio de la relación entre las trayectorias institucionales y la distribución del poder político, y que continúa con un análisis sobre las dimensiones institucionales de las interacciones entre ambos territorios, y en particular del ascenso económico de las minorías religiosas de Oriente Medio junto a la pérdida de rendimiento económico de los musulmanes a partir del siglo XVIII.

A lo largo de la obra, Kuran expone detalladamente distintos elementos clave de la Sharia como las regulaciones sucesorias, la prohibición de la usura o la pena de muerte por apostasía, justificando el porqué de su papel frustrante del desarrollo económico en las zonas de influencia. En este sentido es verdaderamente interesante la pedagogía de la obra: Kuran apunta casos relacionados con ese particular derecho contractual como la disolución de una sociedad por voluntad de cualquier socio, o la no posibilidad de heredar su participación la familia ante su muerte, que llevarían a que alianzas comerciales sostenibles en el tiempo no surgiesen, que las empresas privadas fuesen atomistas y que la cooperación entre empresas adoptase un carácter temporal. Abunda en el tema sucesorio, haciendo hincapié en la naturaleza igualitaria de las leyes islámicas de herencia, que con el fin de evitar la acumulación de la riqueza en pocas manos, tuvieron como efecto la ausencia de imperios empresariales sostenibles. De gran interés es otro apunte: cómo la prohibición de la usura que impedía el crédito y los bancos llevaba a una versión de mercado negro prestamista así como a elevaciones de los costes que difícil solución podían tener, pues además, en ningún momento, se podía acudir a negocios con no musulmanes por el miedo al castigo por apostasía.

Paralelamente a este estancamiento organizativo, Occidente crearía desde el fin de la Edad Media el escenario en el que se cocinaría el caldo para que surgiesen sociedades de mayor tamaño y sostenibilidad, de formas empresariales compatibles con operaciones comerciales a gran escala sostenibles en el tiempo, y cuyo crecimiento fue en gran parte debido a la innovación organizativa, devengando en un comercio cada vez más impersonal, donde el intercambio entre desconocidos se tornó práctica habitual, lo que era incompatible con la ley islámica. Así, en Oriente Medio, se llevarían a cabo políticas antimercantilistas que desatenderían el desarrollo de agricultura, industria y comercio y no incentivarían la innovación, a ello Kuran añade la observación de que a la vez la región dejaría de ser el centro de las rutas comerciales terrestres del mundo, perdiendo así su ventaja comercial.

Otro apunte importante del profesor Kuran parte del aumento durante el siglo XVIII del flujo comercial entre Europa occidental y Oriente Medio, el cual generaba el problema de reducir las incertidumbres contractuales inherentes al comercio transnacional, así como minorar las diferencias en los logros económicos entre comunidades diferentes originadas por sus diferentes ordenamientos jurídicos comerciales. Ello derivaría a una situación de privilegios con respecto a las empresas occidentales que llegarían a contar con sus propios tribunales para resolver litigios, con nuevos métodos de financiación y modelos organizativos, y con la regulación de sus patrimonios según la legislación europea. Según la ley islámica, judíos y cristianos podían elegir a qué ley acogerse en asuntos mercantiles y financieros, lo que les confirió una gran ventaja y contribuyó a aumentar la divergencia económica con los musulmanes. Otro obstáculo importante que señala Kuran en el tránsito hacia las relaciones económicas modernas fue la persistencia, hasta el siglo XIX, de los contratos verbales, situación incompatible con el desarrollo de empresas de gran escala.

En definitiva, y abundando en el argumento de que Oriente Medio tardó mucho en adoptar instituciones clave de la economía moderna, esenciales para el desarrollo económico, Kuran señala cómo, a pesar de que durante los siglos XIX y XX sí que se llevaron a cabo reformas que permitieron en parte adoptar escenarios occidentales, la región sigue configurada como atrasada económicamente, lo que viene explicado por la herencia institucional de la región y las malas políticas en ella sustentadas. Kuran alude a la persistencia de las influencias históricas, que se refleja en la falta de instituciones complementarias, en la debilidad de la sociedad civil y en las reacciones del ordenamiento jurídico tradicional a los fracasos económicos de la región, muy per- 
judiciales para la economía, como las perturbaciones sociales y las inseguridades políticas. Pero según Kuran se podían haber adoptado las instituciones modernas sin mantener las instituciones complementarias supervivientes disfuncionales, y por otra parte tampoco puede achacarse a la religión o al conservadurismo la responsabilidad fundamental de que el proceso de actualización no se haya completado todavía, pues Oriente Medio experimentó cambios institucionales a gran escala durante los últimos dos siglos, demostrando la compatibilidad del islam con la transferencia institucional de otras religiones y civilizaciones.

En sus conclusiones Kuran proyecta un doble mensaje sobre el futuro del Oriente Medio islámico y su desempeño en la economía mundial actual. Por un lado de perfil pesimista, al no considerar un horizonte a corto plazo fuera del subdesarrollo y carente de competitividad en el mercado mundial, dadas la debilidad de su sociedad civil, la excesiva burocracia estatal, la persistencia de malas políticas públicas y normas sociales perjudiciales, añadiendo la negativa influencia para la modernización de la ley islámica clásica. Sin embargo considera un aspecto positivo, que la región adoptó y aceptó culturalmente las instituciones económicas clave del capitalismo moderno hace mucho tiempo sin entenderlas incompatibles con el Islam. Otro debate, que puede surgir a raíz de esta lectura, sería si las instituciones occidentales son el mejor modelo posible para el desarrollo, pero no es la pretensión de Kuran adentrarse en él. 